\title{
THE COLLISIONS BETWEEN UNMANNED AERIAL VEHICLES AND MANNED AIRCRAFT \\ KOLIZJE BEZZALOGOWYCH STATKÓW POWIETRZNYCH Z ZALOGOWYMI STATKAMI POWIETRZNYMI
}

\author{
Leszek Cwojdziński, Jerzy Lewitowicz, Andrzej Żyluk \\ Instytut Techniczny Wojsk Lotniczych \\ e-mail:samolot221@wp.pl,jerzy.lewitowicz@itwl.pl,andrzej.zyluk@itwl.pl
}

\begin{abstract}
Combat missions of both a single multi-role manned aircraft (MMRA) and a group of aircraft. Unmanned aerial vehicles (UAVs) and operations thereof. Airspace for combat missions. Issues of UAV control. Scenarios of air operations with MMRA and UAVs engaged. The risk of collision in the airspace. Probability that flight routes overlap and hence, the risk of collision.
\end{abstract}

Keywords: multi-role aircraft, unmanned aerial vehicle, air combat mission, risk of collision

Streszczenie: Misje bojowe pojedynczego załogowego samolotu wielozadaniowego (ZSW) i grupy samolotów. Bezzalogowe statki powietrzne (BSP) i ich misje operacyjne. Przestrzeń dzialań bojowych. Problemy sterowania BSP. Scenariusze operacji powietrznych z udziatem ZSW i BSP. Ryzyko kolizji $w$ przestrzeni powietrznej. Prawdopodobieństwo nakładania się tras lotu i ryzyko kolizji.

Stowa kluczowe: samolot wielozadaniowy, bezzałogowy statek powietrzny, lotnicza misja bojowa, ryzyko kolizji 
The collisions between unmanned aerial vehicles and manned aircraft

Kolizje bezzałogowych statków powietrznych z zalogowymi statkami powietrznymi

\section{Wprowadzenie}

Problem ryzyka wystąpienia kolizji w przestrzeni powietrznej jest bardzo ważnym zagadnieniem ze względu na bezpieczeństwo, ponieważ następstwem każdej pojedynczej kolizji są dwie katastrofy.

W przestrzeni powietrznej, w przestrzeni działań bojowych, w której występuje duże zagęszczenie ruchu lotniczego kluczowym parametrem jaki musi być brany pod uwagę przy planowaniu tras przelotów jest separacja przestrzenna pomiędzy statkami powietrznymi załogowymi (SP) i bezzałogowymi (BSP). W pracy wykorzystano model Reicha [3, 5, 7]. Model został opracowany dla statków powietrznych $\mathrm{w}$ celu oszacowania ryzyka wystąpienia kolizji (na określonym poziomie prawdopodobieństwa) i badania separacji pomiędzy samolotami wykonującymi loty na podobnych trasach.

Bezzałogowy statek powietrzny (BSP) to napędzany obiekt powietrzny, który nie przenosi człowieka operatora, wykorzystuje siły aerodynamiczne, które zapewniają siłę nośną i umożliwiają sterowanie obiektem, może lecieć sam (autonomicznie) lub być zdalnie pilotowany (sterowany), co jest również bardzo istotne, może służyć jako obiekt jednorazowego użytku lub jako obiekt do odzyskania po zakończeniu lotu. Taka konstrukcja jest zdolna do przenoszenia lotniczych środków bojowych oraz ładunków użytecznych $[1,6]$.

Użytkowanie BSP wymaga złożonych struktur organizacyjno-technicznych, które tworzą system zwany systemem bezzalogowych statków powietrznych (SBSP). System zawiera zestaw BSP, stację naziemną sterowania i naprowadzania, obróbki pozyskiwanych danych, struktury eksploatacji BSP (instalacji wyposażenia, uzbrajania, remontu itp.) i logistyki (zaopatrzenia). Tego rodzaju bezzałogowe systemy mogą podejmować różne zadania bojowe i cywilne takie, jak rozpoznanie różnych sytuacji na ziemi czy bezpośrednie wsparcie lotnicze do niszczenia celów naziemnych (nawodnych).

BSP może być wyposażany $\mathrm{w}$ różne zestawy urządzeń $\mathrm{w}$ zależności od przygotowywanej misji to jest: radary, kamery, zestawy radioelektroniczne i podsłuchowe, zestawy uzbrojenia lotniczego. Brak jest w wyposażeniu urządzeń zbliżonych do TCAS - pokładowego systemu antykolizyjnego ostrzegania o niebezpieczeństwie zbliżaniu się statków powietrznych $\mathrm{w}$ powietrzu, jakie stosowane jest na samolotach. Stanowisko operatora (nawigatora) wyposaża się $\mathrm{w}$ urządzenia transmisji i odbioru danych $\mathrm{w}$ czasie rzeczywistym. Instalowane urządzenia (radary, kamery telewizyjne, kamery na podczerwień) mogą obserwować zaplanowane obiekty powierzchniowe i punktowe, w dzień i w nocy, ale nie informują o możliwych zderzeniach. BSP może wykonać zadanie autonomicznie. Dla tego celu wszystkie dane do lotu wprowadza się przed lotem. Proces sterowania BSP i zapewnienia bezpieczeństwa misji jest bardzo trudny do realizacji ze względu na złożoność obiektów sterowania, ich różnorodność oraz stawiane wymagania. System naziemnej stacji kontroli lotu musi mieć możliwość działania w różnych warunkach, w jakich działała BSP, oraz w zależności od tego, jaki rodzaj misji ma być wykonywany przez obiekt sterowania. 
Złożoność problemów związanych $\mathrm{z}$ obserwacją polega na ograniczonej rozdzielczości kamer zainstalowanych na pokładzie, wibracji oraz zmian parametrów optycznych, warunków atmosferycznych w jakich realizowany jest lot. Zainstalowane kamery na pokładzie BSP są warunkiem koniecznym do zapewnienia bezpiecznego wykonania misji, w trakcie lotu autonomicznego, ale nie jest warunkiem wystarczającym. Na dzień dzisiejszy BSP nie posiadają autonomicznych urządzeń antykolizyjnych, cywilne i wojskowe uregulowania prawne regulujące loty BSP są doskonalone ale trudne do stosowania w warunkach bojowych operacji powietrznych $[2,4]$, co było już powodem ich kolizji na ziemi i z samolotami (rys. 1).

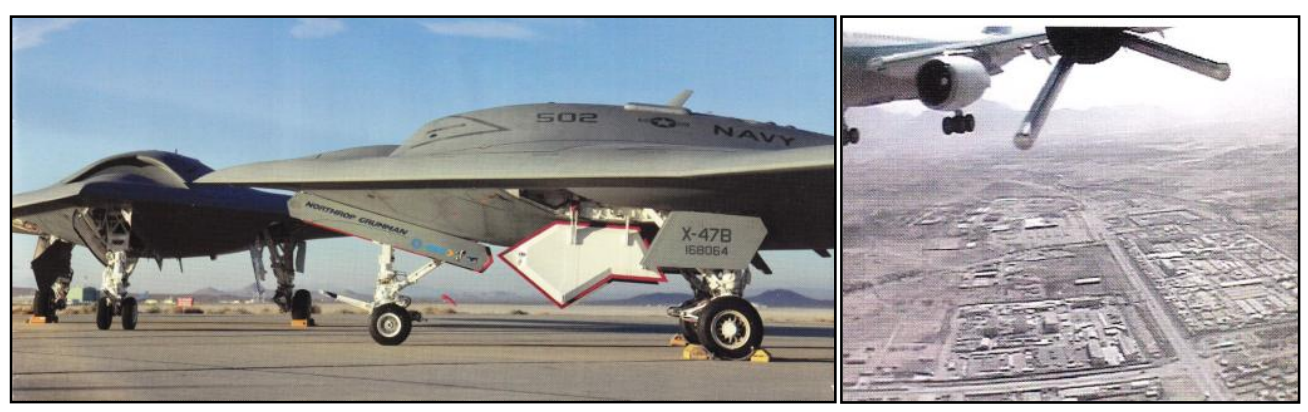

Rys.1. Kolizja BSP na ziemi i zderzenie BSP z samolotem (fot. AW\&ST)

\section{Matematyczny model lotu statku powietrznego}

Każdy lot statku powietrznego (załogowego i bezzałogowego) to realizacja operacyjnego zadania lotniczego (OZL).

Lot statku powietrznego można scharakteryzować zbiorem dwustanowych zmiennych losowych $\{\mathrm{X}\}=\left\{X_{i}\right\}$, gdzie $i=[1, M]$ numeruje kolejną, przyjętą do rozważań zmienną losową, a $\mathrm{M}$ - maksymalna liczba zmiennych.

Przykładowo można rozpatrzyć następujące składowe zbioru $\{\mathrm{X}\}$ :

$X_{1}$ - zmienna losowa charakteryzująca niezawodność, objawiająca się możliwością powstania niesprawności w czasie lotu, przyjmująca wartości: $X_{1}=0$, gdy w czasie lotu powstała niesprawność na SP oraz $X_{1}=1$, gdy niesprawność nie pojawiła się;

$X_{2}$ - zmienna losowa charakteryzująca gotowość operacyjną SP (technika) i pilota (załogi), przyjmująca wartości: $X_{2}=0$, gdy nastąpiło zagrożenie niewykonania ZL oraz $X_{2}=1$, gdy takiego zagrożenia nie było;

$X_{3}-$ zmienna losowa charakteryzująca skutki dla bezpieczeństwa lotów, przy czym $X_{3}=0$, gdy nastąpiło zagrożenie bezpieczeństwa lotów oraz $X_{3}=1$, gdy zagrożenie bezpieczeństwa lotów nie nastąpiło; .

$X_{i}-\quad$ kolejna $i$-ta zmienna losowa charakteryzująca lot; 
The collisions between unmanned aerial vehicles and manned aircraft Kolizje bezzałogowych statków powietrznych z zalogowymi statkami powietrznymi

$X_{M}$ - końcowa zmienna losowa charakteryzująca lot ze zbioru, jaki opisuje operacyjne zadanie lotnicze; zmienna ta charakteryzuje wykonanie Z i przyjmuje wartości $X_{1}=0$, gdy zadanie nie zostało wykonane (zrealizowane) oraz $X_{1}=1$, gdy zadanie zostało wykonane.

Zmienne losowe $X_{i}(i=[1, \mathrm{M}])$ są wzajemnie zależne. Tworzą strukturę szeregową. Ich łączny rozkład, wyrażany poprzez prawdopodobieństwo zbioru $\{\mathrm{X}\}$ można zapisać symbolicznie:

$$
\mathrm{P}\{\mathrm{X}\}=\mathrm{P}\left(X_{1}\right) \mathrm{P}\left(X_{2} \quad \mathrm{x} X_{1}\right) \mathrm{P}\left(X_{3} \quad \mathrm{x} X_{2} X_{1}\right) \cdots \mathrm{P}\left(X_{M} \mathrm{x} X_{1}, \cdots X_{i} \cdots X_{M-1}\right)
$$

Wprowadzając symboliczne współczynniki $a$ o wartościach [0,1] można napisać następujące wyrażenia na rozkłady brzegowe realizacji OZL. I tak:

$$
\begin{aligned}
& P\left(X_{i}=1\right)=\sum_{a_{j k l . . m}} P\left(X_{i}=1, X_{j}=a_{j}, X_{k}=a_{k}, X_{l}=a_{l}, \cdots, X_{m}=a_{m}\right) \\
& a_{j k l . \ldots m}=\left\{a_{j}, a_{k}, a_{l}, \ldots, a_{m}\right\} \\
& a_{j}, a_{k}, a_{l}, \ldots, a_{m}=\left\{\begin{array}{l}
0 \\
1
\end{array} j, k, l, \cdots, m \neq 1\right\}
\end{aligned}
$$

Wyrażenie (2) przyjmuje następującą postać ogólną dla $\mathrm{i} \neq \mathrm{j}$ :

$$
\begin{aligned}
& P\left(X_{i}=1, X_{j}=1\right)=\sum_{a_{j k l . . m}} P\left(X_{i}=1, X_{j}=1, X_{k}=a_{k}, X_{l}=a_{l}, \cdots, X_{m}=a_{m}\right) \\
& a_{k}, a_{l}, \ldots, a_{m}=\left\{\begin{array}{l}
0 \\
1
\end{array} ;, l, \cdots, m \neq i, j, i \neq j\right\}
\end{aligned}
$$

Wartość oczekiwaną i wariancję zmiennych losowych $X_{i}$ wyznacza się z zależności:

$$
\begin{gathered}
\mathbf{E}\left[X_{i}\right\}=P\left(X_{i}=1\right) \\
\sigma_{X_{i}}=\left\{\left[X_{i}-\mathbf{E}\left(X_{i}\right)\right]^{2}\right\}=P\left(X_{i}=1\right)\left[1-P\left(X_{i}=1\right)\right]
\end{gathered}
$$

a kowariancja zmiennych $X_{i} X_{j}$ i współczynnik korelacji z zależności:

$$
\begin{gathered}
\sigma_{X_{i} X_{j}}=P\left(X_{i}=1, X_{j}=1\right)-P\left(X_{i}=1\right) P\left(X_{j}=1\right) \\
\rho_{X_{i} X_{j}}=\frac{\sigma_{X_{i} X_{j}}}{\sigma_{X_{i}} \sigma_{X_{j}}}
\end{gathered}
$$


Obliczenie prawdopodobieństwa $P\left(X_{i}\right)$ ma swoje interpretacje obrazujące pomyślne zakończenie lotu:

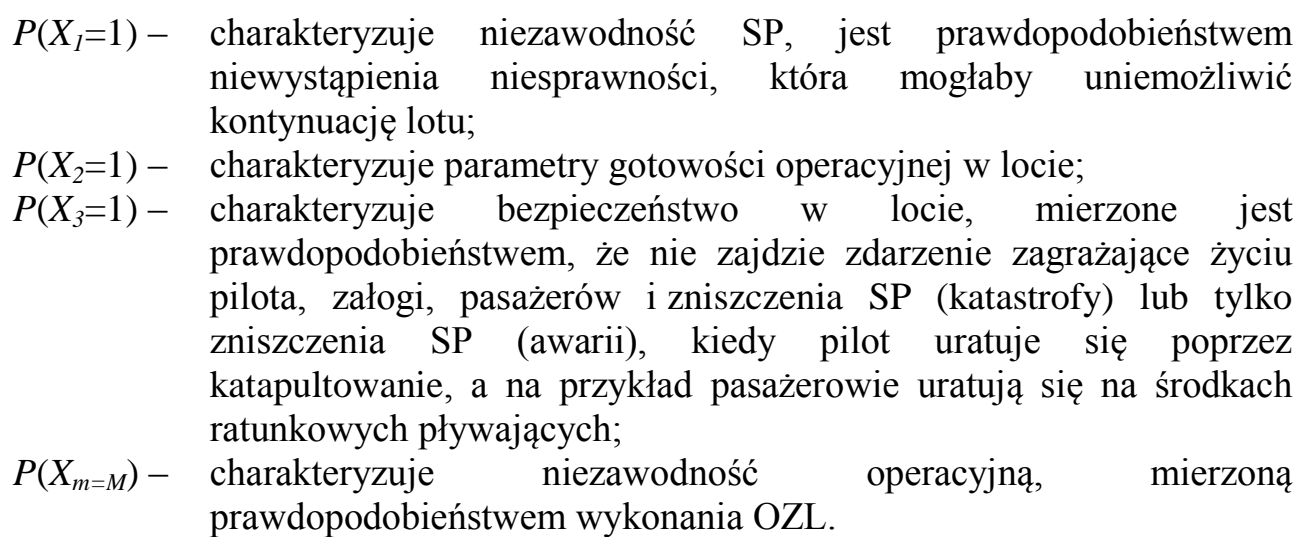

\section{Ryzyko kolizji załogowego i bezzałogowego statku powietrznego}

Ryzyko kolizji statków powietrznych w znacznym stopniu zależy od zapewnienia pionowej lub poziomej separacji przez organa ATC, pod warunkiem utrzymywania własnej separacji i pozostawania $\mathrm{w}$ warunkach meteorologicznych dla lotów $\mathrm{z}$ widzialnością (VFR).

Obowiązujące minima ICAO dla separacji bocznej lub podłużnej można w określonych okolicznościach zmniejszyć w przypadku gdy przeprowadzona odpowiednia ocena bezpieczeństwa wykaże, że będzie utrzymany uzgodniony z użytkownikami, akceptowalny poziom bezpieczeństwa.

Biorąc pod uwagę fakt braku pilota na pokładzie bezzałogowego statku powietrznego, stosowne zmniejszenie ryzyka kolizji wymaga zwiększenia używanych aktualnie w lotnictwie załogowym wartości separacji, w przestrzeni powietrznej kontrolowanej. Separacje większe od określonych minimów, powinny mieć zastosowanie tylko w sytuacjach wymagających tego typu działań, ponieważ zastosowanie nadmiernych wartości separacji, mogłoby doprowadzić do szeregu niepotrzebnych utrudnień w zintegrowanym (załogowym i bezzałogowym) ruchu lotniczym.

Bezpieczeństwo Lotów w przestrzeniach służb ruchu lotniczego jest problemem niezwykle złożonym i trudnym do osiągnięcia wymaganego poziomu ryzyka kolizji nawet w lotnictwie załogowym. Dlatego zagadnienie bezpieczeństwa lotów BSP musi być rozpatrywane $\mathrm{w}$ dwóch płaszczyznach. Po pierwsze w połączeniu $\mathrm{z}$ lotnictwem załogowym $\mathrm{w}$ przestrzeni powietrznej kontrolowanej $\mathrm{w}$ ramach jednolitego, globalnego systemu BL, a po drugie w płaszczyźnie bezpieczeństwa lotów BSL i załogowych statków powietrznych poza przestrzenią kontrolowaną. 
The collisions between unmanned aerial vehicles and manned aircraft

Kolizje bezzałogowych statków powietrznych z zalogowymi statkami powietrznymi

O bezpieczeństwie lotów decydują między innymi:

- stan techniczny BSL oraz systemów kierowania, zdalnego sterowania i łączności;

- systemy antykolizyjne;

- kryteria separacji;

- zasady sterowania i kontroli w aspekcie integracji z lotnictwem załogowym;

- wyszkolenie załóg operujących BSP.

Kolizja statków powietrznych (np. SP1 i SP2) operujących w przestrzeni powietrznej może nastąpić w każdej chwili kiedy wektor odległości $\vec{r}$ pomiędzy nimi zmniejszy się do wartości bliskiej zeru w przestrzeni zderzenia - obszaru kolizji (rys. 2).

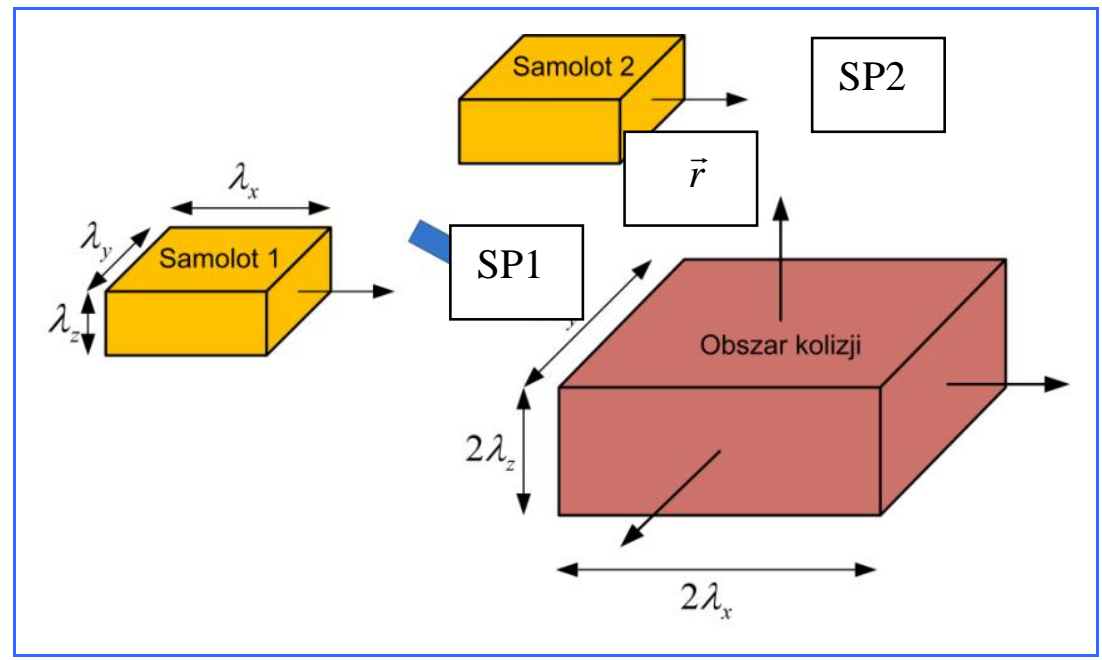

Rys. 2. Graficzna interpretacja obszaru statków powietrznych i obszaru kolizji wedtug modelu Reicha

Liczba kolizji przy utracie separacji poziomej lub pionowej wynosi [ 7]:

$$
N_{a y}=P_{y}\left(S_{y}\right) \cdot P_{z}(0) \cdot\left\{N_{y}(s) \cdot\left[1+\frac{\lambda_{x}}{v_{r x}(s)} \cdot\left(\frac{v_{r y}}{\lambda_{y}}+\frac{v_{r z}}{\lambda_{z}}\right)\right]+N_{y}(o) \cdot\left[1+\frac{\lambda_{x}}{v_{r x}(o)} \cdot\left(\frac{v_{r y}}{\lambda_{y}}+\frac{v_{r z}}{\lambda_{z}}\right)\right]\right\}
$$

gdzie:

$N_{a y}{ }^{-}$liczba kolizji w wyniku utraty separacji poziomej pomiędzy dwoma samolotami;

$S_{y}$ - minimalna separacja pozioma (lateralna); 
$P_{y}\left(S_{y}\right)^{1}$ - prawdopodobieństwo zajścia zdarzenia polegającego na tym, że pozioma separacja samolotów wykonujących lot na sąsiednich trasach (nominalnie wynosząca $S_{y}$ ) będzie równa lub mniejsza niż $\lambda_{y}$;

$P_{z}(0)$ - prawdopodobieństwo zajścia zdarzenia polegającego na tym, że pionowa separacja samolotów wykonujących lot po tej samej trasie będzie równa lub mniejsza niż $\lambda_{z}$;

$N_{y}(s)$ - częstotliwość mijania się samolotów wykonujących lot na sąsiednich trasach i w tym samym kierunku;

$N_{y}(o) \quad$ - częstotliwość mijania się samolotów wykonujących lot na sąsiednich trasach i w przeciwnych kierunkach;

$v_{r x}(s)$ - prędkość względna samolotów wykonujących lot w tym samym kierunku (składowa prędkości w osi $x$ );

$v_{r x}(o)$ - prędkość względna samolotów wykonujących lot w przeciwnych kierunkach (składowa prędkości w osi $x$ );

$v_{r y} \quad$ - składowa $y$ prędkości względnej samolotów;

$v_{r z} \quad$ - składowa $z$ prędkości względnej samolotów;

$\lambda_{x} \quad$ - dhugość samolotu;

$\lambda_{y} \quad-$ szerokość samolotu;

$\lambda_{z} \quad-$ wysokość samolotu.

Prawdopodobieństwo bocznego nakładania się tras statków powietrznych jest krytycznym parametrem z punktu widzenia szacowania ryzyka kolizji statków powietrznych (w różnych konfiguracjach załogowych i bezzałogowych) wykonujących loty na równoległych trasach. Prawdopodobieństwo to może być szacowane na podstawie funkcji gęstości prawdopodobieństwa błędu ich pozycji odbywających loty na analizowanych trasach.

Prawdopodobieństwo bocznej kolizji statków powietrznych wykonujących lot na sąsiednich trasach możemy wyraża się następującym wzorem [7]:

$$
P_{y}\left(S_{y}\right)=\int_{S_{y}-\lambda_{y}}^{S_{y}+\lambda_{y}} C(z) \mathrm{d} z
$$

gdzie:

$S_{y} \quad$ - zakładana separacja pozioma pomiędzy trasami;

$\lambda_{y} \quad$ - przeciętna szerokość (rozpiętość skrzydeł) statku powietrznego;

${ }^{1}$ Ang. lateral overlap probability 
The collisions between unmanned aerial vehicles and manned aircraft

Kolizje bezzałogowych statków powietrznych z zalogowymi statkami powietrznymi

oraz:

$$
C(z)=\int_{-\infty}^{\infty} f(x) f(x-z) \mathrm{d} x
$$

oznacza gęstość prawdopodobieństwa nakładania się tras np. załogowego i bezzałogowego statku powietrznego, natomiast $f(x)$ i $f(x-z)$ oznaczają funkcje gęstości prawdopodobieństwa zmiennej losowej $X$ będącej błędem pozycji statków powietrznych na równoległych trasach.

\section{Podsumowanie}

BSP i lotnictwo załogowe wykorzystują tę samą elementy przestrzeń powietrzną, te same organa kontroli ruchu lotniczego i służby informacji o sytuacji powietrznej oraz te same przepisy i procedury realizacji zadań w powietrzu i na ziemi. Przy czym aspekt braku pilota na pokładzie BSP powinien znaleźć swe odzwierciedlenie $\mathrm{w}$ dostosowaniu obowiązujących przepisów i procedur wykonywania lotów w przestrzeni powietrznej kontrolowanej.

Integracja BSP $\mathrm{z}$ lotnictwem załogowym $\mathrm{w}$ przestrzeni powietrznej nie jest problemem lokalnym, jest globalnym, wymagającym wielkiej koordynacji. Tylko takie działania warunkują zmniejszenia możliwości kolizji w powietrzu pomiędzy załogowymi i bezzałogowymi statkami powietrznymi. BSL muszą bezpiecznie wykonywać zadania w przestrzeni działań bojowych, bez potrzeby ich izolacji od innych użytkowników przestrzeni powietrznej. Utrzymywanie wysokiego poziomu bezpieczeństwa lotów jest kluczowe dla wszystkich dowództw wykorzystujących statki powietrzne w przestrzeni działań bojowych.

Aby bezzałogowe statki powietrzne mogły spełniać takie same kryteria jak lotnictwo załogowe, muszą być wyposażone w adekwatne systemy typu TCAS/ACAS, posiadające dodatkowo odpowiednie rozwiązania konstrukcyjne, zapewniające przekazywanie stosownych informacji pilotowi BSL usytuowanemu w GCS (ZKP), który mógłby na tej podstawie ominąć przeszkodę, zdalnie sterując samolotem.

Szczególną rolę odgrywa integracja organów sterujących działaniem BSP $\mathrm{z}$ organami kontroli ruchu lotniczego.

\section{Literatura}

[1] Cwojdziński L.: Unamanned aerial systems. International Conference TRANSCOMP. Zakopane 2012.

[2] Dołęga B., Gruszecki J., Tomczyk A.: Uwarunkowania strukturalne systemów bezzalogowych zależne od rodzaju wykonywanej misji. Konferencja Naukowo-Techniczna Bezzałogowe Statki Powietrzne w Polsce. Warszawa 2012.

[3] Endoh S.: Aircraft Collision Models. Massachusetts Institute of Technology. Cambridge MA. 1982. 
[4] Massutti A.: A regulatory framework to introduce unmanned aircraft system in civil airspace. ICAO/CERG Warsaw Air Law Conference. Warsaw 2012.

[5] Nagaoka S.: A Model for Estimating the Lateral Overlap Probability of Aircraft with RNP Alerting Capability in Parallel RNAV Routes. $26^{\text {th }}$ International Congress of Aeronautical Sciences, Anchorage-Alaska 2008.

[6] Richard K.: Introduction to unmanned aircraft systems. CRC Press. New York, 2012.

[7] Sajda K., Lewitowicz J.: Analiza ryzyka kolizji statków powietrznych w kontrolowanej przestrzeni powietrznej. Journal of KONBiN 4(7) 2010.

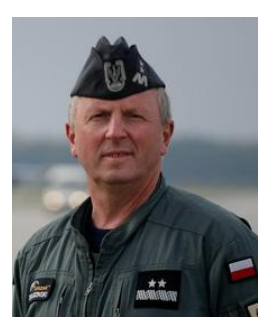

gen. dyw. pil. dr Leszek Cwojdziński- wychowanek Aeroklubu Poznańskiego, absolwent Wyższej Oficerskiej Szkoły Lotniczej w Dęblinie, studia ukończyt z wyróżnieniem w 1979 r. W 1983 r. uzyskat tytut magistra pedagogiki na UMCS $w$ Lublinie. Pilot instruktor. Ukończyt $z$ wyróżnieniem Akademię Lotnicza Sit Powietrznych im. Jurija Gagarina w Monino (Rosja). Prace doktorska $z$ teledetekcji - rozpoznania obrazowego obronit w Wojskowej Akademii Technicznej. Ukończyt kurs oficerów flagowych w NATO Defense College $w$ Rzymie. Autor licznych prac naukowych dotyczacych techniki lotniczej, uzycia bojowego statków powietrznych $i$ szkolenia lotniczego. Petni funkcję Dyrektora Departamentu Polityki Zbrojeniowej. Posiada nalot 2400 godzin na samolotach odrzutowych i tytut pilota wojskowego klasy mistrzowskiej.

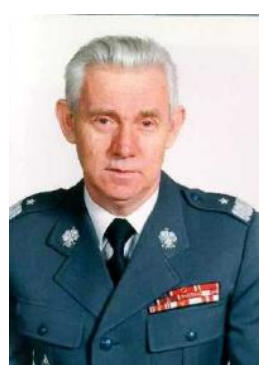

Prof. Dr hab. inż. Jerzy Lewitowicz. Absolwent Wojskowej Akademii Technicznej i Uniwersytetu Warszawskiego. Główne zainteresowania: rozwój najnowszej techniki wojskowej, w tym w szczególności lotniczej, budowa $i$ eksploatacja samolotów $i$ śmigłowców ze szczególnym uwzględnieniem diagnostyki. Posiada ponad 50. letni staż naukowy $i$ dydaktyczny $w$ Instytucie Technicznym Wojsk Lotniczych i na Politechnice Warszawskiej. Jest członkiem SIMP, AIAA, ICAS. Wieloletni członek trzech komitetów Polskiej Akademii Nauk: Fizyki, Budowy Maszyn, Badań Kosmicznych i Satelitarnych. Autor licznych publikacji naukowych (ponad 400). Autor i współautor 23 książek naukowych z dziedziny eksploatacji statków powietrznych, tribologii, diagnostyki, bezpieczeństwa lotów, licznych patentów oraz wzorów użytkowych. Posiada stopień wojskowy generała brygady (w rez.). Jest pracownikiem naukowym Instytutu Technicznego Wojsk Lotniczych.

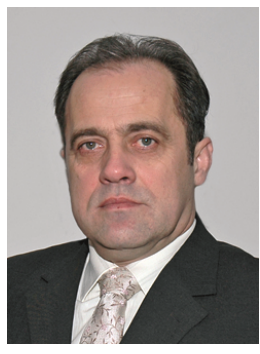

Prof. nadzw. dr hab. inż. Andrzej Żyluk. Absolwent wydziału Elektromechanicznego Wojskowej Akademii Technicznej w 1985 roku $w$ dziedzinie konstrukcji i eksploatacji uzbrojenia lotniczego. Jest pracownikiem naukowym w ITWL i petni obowiąki zastępcy dyrektora ds. naukowo-badawczych ITWL. W dorobku naukowym posiada ponad 60 publikacji naukowych zzakresu badań $i$ eksploatacji statków powietrznych, w tym w szczególności systemów uzbrojenia lotniczego, badania wypadków lotniczych, modelowanie matematyczne systemów technicznych. Posiada stopień wojskowy podpułkownika w rezerwie. 
The collisions between unmanned aerial vehicles and manned aircraft Kolizje bezzałogowych statków powietrznych z załogowymi statkami powietrznymi 